UDC 1(091):2-1

Seyran ZAKARYAN

\title{
THE PROBLEM OF ETERNITY OF THE WORLD IN THE PHILOSOPHICAL-THEOLOGICAL THEORY OF GRIGOR TATEVATSI
}

\begin{abstract}
The famous Armenian theologian and philosopher Grigor Tatevatsi (1346-1409) in his teaching tries to compare the biblical truth of creation with the philosophical postulate regarding the eternity of the world. Principally, being a creationist thinker, he criticized the theories that made the Materia co-eternal to God, meanwhile, he proposed the following arguments regarding the eternity of the world: a) before the creation the world existed actually by influence in the providence of God as an immaterial paradigm; b) the world is eternal because it is linked to eternity; c) the God is the eternal and always actual being, therefore the world was created eternal and the eternal is the necessary being which never can become none-being; d) the will of God is unchangeable, He cannot make the created world become non-being otherwise His will would change; e) the God does not make the world become non-being not because $\mathrm{He}$ is unable to do so but due to the boundless goodness; f. the world is eternal because the four elements and qualities that are the basis of it, are eternal. Therefore, even though the arguments proposed by Tatevatsi are based on and contain typical ideas of Neoplatonism, one has to take into account that he speaks of the eternity of the created world rather than co-existence of world with the God.
\end{abstract}

Keywords: Grigor Tatevatsi, Creationism, God, Will of God, Creation, Eternity of the World, Actuality, Potentiality, Necessary Being, Time.

The question of the Eternity of the world became an object of the bitter discussion in the XIII century, when European thinkers were acquainted with the teachings of Ibn Sina, Ibn Rushd and Aristotle. After lengthy debates new books, with the title «De aeternitate mundi», «The Eternity of the World», (David of Dinant, Siger of Brabant, Thomas Aquinas etc.), appeared; and proposition «the world is eternal», regarded as avveroistic, was condemned by Etienne Tempier, the bishop of Paris, in 1270 and 1277. In the medieval Armenian philosophy this question was thor- oughly discussed in the XIV century, when Armenian thinkers, particularly the Tatev University representatives Hovhan Vorotnetsy (1315-1388) and Grigor Tatevatsi (13461409), enlarged their knowledge on antique philosophy (the first nature philosophers, Plato, Aristotle, stoics) and on teachings of Ibn Sina and Ibn Rushd due to the translations into Armenian of the works of Albert the Great, Thomas Aquinas and others; and also due to works of based in Armenia catholic missioners, members of the Dominican Order, Bartholomew of Bologna $(\uparrow 1333)$ and Peter 
of Aragon (†1347). If Bartholomew of Bologna, Peter of Aragon and Hovhan Vorotnetsy criticized and rejected the ancient materialistic and dualistic, Aristotelian and Neoplatonian teachings, included the teachings of Ibn Sina and Ibn Rushd concerning the eternity of the world (the matter), Grigor Tatevatsi admitted the notion of the eternity of the world, using some statements from the criticized theories. In other words, he combined the notion of creation of the world out of nothing with the notion of eternity of the world. But how is it possible to combine incompatible? How could the famous theologian in this principal question agree with the statement that contradicts with biblical, scriptural truth? Such questionings naturally emerge, first of all because Tatevatsi though preferred to follow the negative (apophatic) method of the God cognition, still tried to explain the existence and nature of the God, the essence of the creation, and the relation of the God and the world by means of philosophical (Aristotelian) concepts. He was convinced that by means of rationality one can and must prove the truths of Revelation, particularly the biblical proposition of creation of the world out of noting.

For Tatevatsi it is an evident and undeniable truth, that the God is the creator, who created the whole universe, the intelligible and sensible existences, ex nihilo, out of noting. He is a creationist thinker indeed, and naturally, does not defend neither the statement of the ancient thinkers (for example, Aristotle) concerning the eternity of the world (in this case, the statement of eternal co-existence of the world with the God), nor the neoplatonic statements about the eternity of the first cause and the results. Arguing against the statement «noting comes from noting», Tate- vatsi tries to explain the divine creation out of noting by means of Aristotelian concepts. He distinguishes two types of noting, a) absolute noting, or possible existence, which is without influence, and b) noting or possible existence with influence. The God is mere reality and eternal influential existence, and the matter is non-existence, but an existence by possibility. The world is created out of such possible existence or noting with the influence. Indeed, the usage of the concepts of two types of the noting or the concepts of «the reality» and «the possibility» can cause other explanations, but it would be erroneous to conclude that Tatevatsi with this theory «factually denies the creation of the world out of noting» (Arevshatyan, 1957, p. 61) or makes an allusion about co-existence of the matter with the God. Both the time and the matter are the results of divine creation and cannot be coexistent with the God. Answering to the question how the God, having non-material and simple essence, can create material existences, Tatevatsi writes, that the God creates out of noting non-material essences (formation, quantity, quality, etc.) and collecting them by his power, constitutes bodily substance, and out of this creates material elements and elementary bodies. Based on this and analogical statements we can state that Tatevatsi regardless the fact that he uses Aristotelian concepts and somehow deviates from religious perceptions, however defends the notion of the creation of the world.

The question of the eternity of the world Tatevatsi raises aiming to discuss whether the God can turn into non-existence not created yet and created world. Answering to this question Armenian thinker proposes some metaphysical and moral arguments supporting 
the eternity of the world. As follows:

A) The world is eternal, because it exists in the eternal God as providence. The world with influence exists before the creation in the God's mind, namely, the world is co-existent with the God not as an autonomic material substance, but as an immaterial and unchangeable paradigm. Like a craftsman (a sculptor) before inscribing an image on the stone firstly paints that image in his mind and then sculpts it, as well as the God firstly in his mind has the image of the world that will be created, particularly, general prototypes of the things that will be created (Tatevatsi, 1746, p. 522). In this sense «the beginning of the existence of the world is twice», firstly, when it exists in the God's mind, as a notion of a temple in the head of an architect, secondly, when it is created, that is the temple is constructed. Tatevatsi uses a method of analogy trying to explain the fact of a double existence of the world by the example of a craftsman (an architect) and a temple, noting indeed that between the original and the copy there are similarities and differences. For example, if the image of a temple can be erased in the mind of an architect, forgotten, then the image of the world in the God's mind never can be erased. The world is eternal, because if in the mind of an architect the temple exists by possibility, then by influence, and then «being of the world by power is by God's influence» (Tatevatsi, 1729, p. 169). Noting can be by possibility in the God as the being by possibility implies a change, while the God is an unchangeable essence, namely is «unmovable by vision and will». The eternity of the world first of all is caused by the eternity of divine providence. The God is eternal, so everything in Him is also eternal. In this sense the God is unable to turn the world into non-existence. Moreover, according to him the world necessarily will receive its being from adequate immaterial paradigm, because «it is impossible for the beginning of the existence of the world be other than was as a prototype in the vision of the God» (Tatevatsi, 1729, pp. 164165). At first glance, this is an extremely rationalistic (in this case necessistic) commentary of the God and His action, which in essence does not leave a space for the volitional action of the God. But here the point is not the restriction of the God's will, instead it means that if in God's mind a prototype of a future creation exists, if the God decided to create something, it will be created necessarily, that is the God's will should be realized, as there could not be a contradiction between the God's will and providence. Anyway, in other places Tatevatsi avoids similar expressions, explicating that the creation of the world is a voluntary and not necessary action.

B) The world is eternal as it is in the communion with the God. According to Tatevatsi one must differ «eternity» from «always» (everlasting) and from «time» as a) Eternity like the God does not have neither the beginning, nor the end. Eternity is not an endless duration of time, but a realm that exists out of the space-time frame. b) Everlasting has a beginning, but not an end, like the angels and souls, c) the time has a beginning and an end, like herbal and sensory-material beings. The God is eternal and is the cause of the everlasting and the time. The time consists of three parts: past, present, future, but the everlasting and the eternal do not have parts. It is evident that Tatevatsi here considers as an absolute and beginningless only the God, and others as having a beginning, creations. The time has in it 
the everlasting and the eternal, and everlasting has in it the eternal. In this sense the created beings and the world are eternal, because they are in communion with the Eternal: «And angels, and souls, and the world are called eternal, as they communicate with the eternal that is beginningless end endless»" (Tatevatsi, 1729 , p. 116). In this context the statement «the world is eternal» does not contradict with the creationistic position of Tatevatsi. Moreover, being communicated means to see in the world the traces of the eternal (divine) and by means of knowing them to formulate a perception of the divine.

C) The eternity of the world derives from the eternity of the God. As a primary cause the God is a necessary and always influential being and thus it differs from others, which sometimes are existences and sometimes are non-existences, sometimes are by influence and sometimes are by possibility, and in which influence and possibility replace each other. The God is a necessary being, as «has only existence, does not have non-existence, thus He is unchangeable by His essence. He is always by influence, He does not need any beginning and power of perfect, so He is beginningless and endless» (Tatevatsi, 1729, p. 162). The activities of necessary and eternal Existence also must be necessary and eternal. The God is eternal and always by influence, thus He created the world everlasting, but the everlasting is a necessary existence, which cannot turn into non-existence: «God created the world as a everlasting business, and the everlasting is necessary, and the necessary can exist and cannot perish. For this the world became into existence, sometimes by everlasting existence, but never can turn into nonexistence» (Tatevatsi, 1729, p. 162).
In this context Tatevatsi ascribes everlastingness to the world, while, as we saw above he considered as everlasting angels. In these arguments also can be seen the elements of the neoplatonic theory of the eternity of the world. According to the theory of emanation world necessarily is emanated or flew down from the One, and the world is eternal in so far as its eternal creator. This view is defended by Ibn Sina and Ibn Rushd from different grounds, and is criticized by Thomas Acquinas.

If the God is eternal, so everything connected to Him should be eternal. According to Tatevatsi the notion of eternity of the world stems from the eternal and immutable nature of the God: "As the God Self is everlasting, staying and eternal, likewise the world, the result of His glorious Business, will be staying and everlasting. Because though partially it is passing away and destroying, but as a whole it is non-passing, ever-present and everlasting» (Tatevatsi, 1740, p. 272). Thus, according to Tatevatsi the eternity of the world stems from the eternity of the God.

D) The next argument concerning the eternity of the world is connected with the immutability, omnipotence and omnikindness of the God. According to Tatevatsi, God's will is immutable, so if He wants to destroy the world it will mean that His will has been changed, which is impossible. Thus, the world cannot come into non-existence. The God «has wanted by an immutable will and created to existence the world and He is not able to change his immutable will and lead the being to non-existence» (Tatevatsi, 1729, p. 165). Unlike the humans whose will and ability are not equal, in God they are equal and reversible. The God is omnipotent. «As 
whatever He wills $\mathrm{He}$ is able to do and whatever $\mathrm{He}$ is able to do $\mathrm{He}$ is able to will». But the God «does not will the evil and the sinful, so $\mathrm{He}$ is not able to act that way». The last case does not witness about God's inability, in contrary, not doing the evil indicates of superb abilities of God. For example, the sun cannot be dark as it is mainly lightful; similarly the God «is not able to the evil, as mainly $\mathrm{He}$ is able to the kind. And $\mathrm{He}$ is not able not to be as mainly $\mathrm{He}$ is ( $\mathrm{He}$ is the most being existence), etc. Similarly, the God is not able to lead the world to non-existence because of His kind will» (Tatevatsi, 1729, p. 163). Thus, the God does not lead the world to nonexistence not only for metaphysical, but also for ethical reasons.

E) The world is eternal as material elements making its basis are undestroyable. The eternity of the world also means the eternity of its elements: earth, water, air and fire. Tatevatsi mentions that philosophers think so and seemingly agrees with them. Separate things are emerging and destroying, but the underlying elements cannot be destroyed. The philosophers consider elements undestroyable: a) because of the movement of heavenly bodies; they are moving uniformly, constantly, without increasing or decreasing, which provides uninterrupted being and existence of things; b)though the elements are contrary by their qualities, nevertheless they are united and maintain the harmony of existence; c) through existence of being and destroying the destruction of things in its turn causes the origination of new things, and the «elements remain undestroyable in this cyclic process» (Tatevatsi, 1729, p. 181); d) the part are destructing, but the whole remains; individual beings are born and die, but the genus and the species remain; e) the world is «not getting old» as time by time it purifies itself from inner and outer accidents. Concluding, we can state, that Tatevatsi comes from the biblical idea of the world creation and defends only the notion of eternity of the created world. True, though in his argumentation in favor of eternity of the world he uses judgments of neoplatonic and averroistic nature, however they «fit» in the general context of his creationistic theory.

\section{REFERENCES}

Arevshatyan, S. S. (1957). Filosofskie vzglyady Grigora Tatevatsi (Philosophical Views of Grigor Tatevatsi - Grigor of Tatev, in Russian). Yerevan: RA Academy of Sciences Press.

Tatevatsi, G. (1729). Girq harcmanc (The Book of Interpellations, in Armenian). Constantinopolis: Printing house of Mahdesi Asatur.

Tatevatsi, G. (1740). Girq qarozut'yan, vor kochi d'meran hator (The Book of Sermons Called the Winter Volume, in Armenian). Constantinopolis: Printing house of Abraham Dpir.

Tatevatsi, G. (1746). Girq, vor kochi voskeporik (The Book Called Golden Belly, in Armenian). Constantinopolis: Printing house of Abraham Dpir. 